\title{
PHYSICAL, CHEMICAL AND SENSORY PROPERTIES OF INSTANT COCOA POWDER ENRICHED WITH INDUSTRIAL HEMP EXTRACT (Cannabis sativa L.)
}

\section{FIZIKALNA, KEMIJSKA I SENZORSKA SVOJSTVA INSTANT KAKAO PRAHA OBOGAĆENOG EKSTRAKTOM INDUSTRIJSKE KONOPLJE (CANNABIS SATIVA L.)}

\author{
Nikola TALAN, Tamara JURINA, Davor VALINGER, Ana JURINJAK TUŠEK, Jasenka GAJDOŠ KLJUSURIĆ, Maja BENKOVIĆ* \\ University of Zagreb, Faculty of Food Technology and Biotechnology, Pierottijeva 6, 10000 Zagreb, Croatia \\ e-mail:mbenkovic@pbf.hr
}

\begin{abstract}
Lately, cocoa has been studied for its health benefits and its polyphenolic content. Despite the fact that cocoa already possesses functional properties, its functionality is being increased. An emerging way to enhance functional properties of instant cocoa powders is the addition of herbal extracts. The aim of this study was to, using a foam-mat drying process, produce functional instant cocoa powders enriched with 2.5, 5, 10 and $15 \%$ of hemp (Cannabis sativa L.) extracts in aqueous and microencapsulated form. Based on the obtained results it was visible that the type of the added extract affected powder dry matter, total polyphenolic content, antioxidant capacity, cohesion index and foam dry matter. The percentage of the added extract affected bulk density, all sensory properties and the total polyphenolic content. Percentage of the added extract had a more significant influence $(p<0.05)$ on the produced samples and their properties in comparison to the type of the added extract.
\end{abstract}

Key words: instant cocoa powder, foam mat drying, industrial hemp, functional beverages.

\section{REZIME}

Kakao se u posljednje vrijeme sve više istražuje zbog svojeg pozitivnog djelovanja na ljudsko zdravlje, prvenstveno zbog sadržaja polifenola te povezanosti sa smanjenim rizikom od kardiovaskularnih bolesti. Unatoč činjenici da kakao već posjeduje funkcionalna svojstva, na tržištu je svejedno prisutan niz instant kakao proizvoda sa dodatkom različitih vitamina, minerala, vlakana i bioaktivnih spojeva kako bi se dodatno poboljšala njihova funkcionalnost. Jedan od novijih načina poboljšavanja funkcionalnih svojstava instant kakao prahova je obogaćivanje biljnim ekstraktima. Otkriće povoljnih učinaka industrijske konoplje (Cannabis sativa L.) na ljudsko zdravlje dovelo je do ideje o proizvodnji kakao praha obogaćenog ekstraktom konoplje. Stoga je cilj ovoga rada bio, procesom sušenja u pjeni, proizvesti funkcionalne instant kakao prahove obogaćene ekstraktom industrijske konoplje. Ekstrakti su dodavani u dva različita oblika: tekući $i$ mikrokapsulirani u želatinskoj matrici. Osim različitih oblika, varirana je $i$ koncentracija dodanih ekstrakata $(2,5 ; 5 ; 10$ i 15\% w/w). Temeljem dobivenih rezultata vidljivo je da je vrsta dodanog ekstrakta najviše utjecala na suhu tvar praha, sadržaj ukupnih polifenola, antioksidacijski kapacitet, indeks kohezije i suhu tvar pjene, dok je postotak ekstrakta utjecao na nasipnu gustoću, senzorska svojstva i sadržaj ukupnih polifenola. Postotak dodanog ekstrakta imao je značajniji utjecaj (p<0.05) na proizvedene kakao prahove u usporedbi s vrstom dodatka.

Ključne riječi: instant kakao prah, sušenje u pjeni, industrijska konoplja, funkcionalni napici.

\section{INTRODUCTION}

Trends in socio-economic development and population demographics show that in recent years there has been a growing need for development of functional foods, which is explained by the fact that food has become a major factor affecting human health and that health disorders and diseases are related to dietary habits (Živković et al., 2013). One way to produce such functional food products is to enrich the existing products with natural bioactive compounds, which has proven to be a costeffective way of food product improvement (Spence, 2006). On a global scale, the greatest increase of newly developed functional food products is visible in the functional nonalcoholic drinks productions, which are no longer just refreshing, but also show additional positive effects on human health.

Cocoa has been consumed in human nutrition for thousands of years, and for a long time, it was consumed for purely hedonistic reasons. However, over the past 20 years, researchers have shown that dark chocolate (a high proportion of cocoa) and cocoa powder have positive effects on human health, primarily due to the relatively high concentration of polyphenols and antioxidants (Ackar et al., 2013). Furthermore, beneficial health effects of cocoa are well documented in the literature as the ability to lower the blood pressure, reduction of the LDL cholesterol levels, reduction of the risk of heart attack or stroke (Hollenberg et al., 2009, Ndife et al., 2013, Baba et al., 2007), as well as iron and tryptophan abundances, which help alleviate symptoms of anxiety and depression (Cinquanta et al., 2016, Badrie et al., 2015). Despite the fact that cocoa already possesses functional properties, the market is saturated with instant cocoa powders which have been supplemented with different vitamins, minerals, fibers and bioactive compounds to enhance their functionality. One of the emerging ways to enhance functional properties of instant cocoa powders is the addition of herbal extracts.

In the last few decades, the cultivation, development and use of industrial hemp has experienced a significant increase. In addition to traditional uses such as fiber, textile and paper production, the possibilities for application in the medical, food and pharmaceutical industries are increasingly being explored. E.g., industrial hemp is used in the food industry in order to increase the nutritional and functional properties of food products, primarily due to the presence of $\omega-6$ and $\omega-3$ fatty 
acids, terpenes, high-value proteins and antioxidant activity (Hazekamp and Grotehermen, 2010). The discovery of beneficial effects of industrial hemp (Cannabis sativa L.) on human health has led to the idea of producing cocoa powders enriched with hemp extract.

Therefore, the aim of this work was to produce foam mat dried functional instant cocoa powders enriched with two different types of industrial cannabis extract: microencapsulated and liquid. Percentage of the extract was also varied: 2.5, 5, 10 and $15 \%$. Physical properties (particle size, bulk density, dry matter, flow properties, dispersibility and solubility), chemical properties (total polyphenols, antioxidant activity) and sensory properties of the obtained foam mat dried cocoa powders were analyzed.

\section{MATERIALS AND METHODS}

\section{Materials}

The following materials were used for foam preparation: cocoa powder (10\% fat) (Kraš d.d., Zagreb, Croatia), bovine gelatin (Podravka, Koprivnica, Croatia), sucrose (Kraš d.d., Zagreb, Croatia), liquid egg white (Elcon prehrambeni proizvodi d.o.o., Zlatar Bistrica, Croatia), soy lecithin (dm, Karlsruhe, Germany), dried cannabis (Cannabis sativa L.) - whole plant leaves, stem, flower and seeds (OPG Levačić, Prelog, Croatia) and fresh homogenized milk with $3.2 \%$ fat (Vindija d.d., Varaždin, Croatia).

Chemicals used for analyses were: the Folin-Ciocalteu reagent (Kemika, Zagreb, Croatia), sodium carbonate $\left(\mathrm{Na}_{2} \mathrm{CO}_{3}\right)$, p.a. (Gram-mol, Zagreb, Croatia); methanol HPLC grade (J.T. Baker, Deventer, the Netherlands); 1,1-diphenyl-2picrylhydrazyl (DPPH) (Sigma Aldrich, Steinheim, Germany); gallic acid, 98\% (Acros Organics, New Jersey, USA), 6hydroxy-2,5,7,8-tetramethylchroman-2-carboxylic acid (Trolox) (Fluka, Buchs, Switzerland) and acetone, 99.9\% (Gram-mol, Zagreb, Croatia).

\section{Methods}

\section{Liquid extract preparation}

Dried Cannabis sativa L. plant was used to prepare the extract: $4 \mathrm{~g}$ of the dried plant was weighed and mixed with 200 $\mathrm{mL}$ of distilled water pre-heated to $80{ }^{\circ} \mathrm{C}$. The mixture was placed in an oil bath (IKA, Staufen, Germany) at $80^{\circ} \mathrm{C}$ and 500 rpm, for 90 minutes. After completion of the extraction process, the extract was filtered through a cellulose filter paper (LLG Labware, Meckenheim, Germany) and stored at $4{ }^{\circ} \mathrm{C}$ until further use.

\section{Microencapsulated extract preparation}

Matrix type microcapsules containing industrial hemp extract were prepared by adding $0.8 \mathrm{~g}$ of glycerol and $2 \mathrm{~g}$ of gelatine to $20 \mathrm{~mL}$ of liquid hemp extract. The solution was then left to cool in a refrigerator for $10 \mathrm{~min}$. After $10 \mathrm{~min}$ the solution was heated to $80{ }^{\circ} \mathrm{C}$ until all the gelatine was melted. The hot solution was then transferred in a syringe mounted on a NE-300 syringe pump (New Era Pump Systems, USA) with a flow rate of $1 \mathrm{~mL} / \mathrm{min}$. The solution was pumped through a syringe containing a microcapilare tip $(d=50 \mu \mathrm{m})$ into a glass filled with sunflower oil which was constantly cooled in an ice/water mixture. The formed microcapsules were stored in a refrigerator for $60 \mathrm{~min}$ after which the suspension was filtered through a kitchen sieve. Prepared microcapsules were stored in a refrigerator until use.

\section{Foam preparation and drying}

Two sets of samples were prepared based on the type of extract added: liquid extract (samples marked E) and microencapsulated extract (samples marked A), both in concentrations of $2.5,5,10$ and $15 \%$, which makes a total of 8 samples plus a control sample without extract addition. Foam recipe contained $50 \mathrm{~g}$ of the basic cocoa/sugar mixture (30:70 w/w), $0.5 \% \mathrm{w} / \mathrm{w}$ gelatin and $80 \mathrm{~g}$ egg white. The mixtures were prepared by mixing the liquid ingredients (egg white and extract, if contained) for $4 \mathrm{~min}$ using a kitchen blender (Philips, Amsterdam, The Netherlands). Dry ingredients were then slowly added until homogenous foam was obtained. After mixing, the foams were evenly spread $(h=4 \mathrm{~mm})$ into aluminium trays, put in a convectional air dryer (InkoLab, Zagreb, Croatia) and left to dry overnight at $60^{\circ} \mathrm{C}$. Dried foams were milled (IKA Tube mill (IKA-Werk, Staufen, Germany) at $15000 \mathrm{rpm}$ for $10 \mathrm{~s}$ in order to obtain a powdered product. The cocoa powders were stored in $\mathrm{PE}$ bags at $4{ }^{\circ} \mathrm{C}$ until analysed.

\section{Foam properties}

A volume of $10 \mathrm{~mL}$ of the blended foam was put in a graduated cuvette and the initial volume and mass was measured, from which foam density was calculated. The cuvette was left to stand at room temperature for $2 \mathrm{~h}$ and the foam volume was read once again to obtain the foam stability value, which was calculated as the ratio between volume read after $2 \mathrm{~h}$ and the initial volume. All measurements were performed in triplicate.

\section{Powder physical properties}

Particle size distribution of the cocoa powders was determined by laser diffraction particle sizing via Scirocco 2000 dry dispersion unit (Malvern Instruments, UK). Moisture content was determined according to a standardized AOAC method (AOAC, 1990), and bulk density by a jolting volumeter after 10 taps, as previously stated by Benković and Bauman (2012). Cohesion index was determined using a powder rheometer (TA.HDPlus Texture Analyser coupled by a Powder Flow Analyser, StableMicroSystems, Godalming, UK), as previously described by Benković and Bauman (2009).

Reconstitution properties were assessed as dispersibility and solubility according to a method described by HaugaardSorensen et al. (1978). All measurements were performed in triplicate.

\section{Chemical properties}

Total polyphenolic content (TPC) of samples was determined spectrophotometrically according to a modified method of Lachman et al. (1998). Antioxidant capacity was determined using the DPPH method, previously described by Brand-Williams et al. (1995).All measurements were performed in triplicate.

\section{Sensory properties}

Sensory properties of the prepared drinks were evaluated using a 9-point hedonic scale(1-dislike extremely, 9 -like extremely) by a group of trained panellists $(n=5)$. The drinks were prepared in the following manner: $5 \mathrm{~g}$ of cocoa powder was dissolved in $100 \mathrm{~mL}$ of milk with $2.8 \%$ fat (Dukat, Zagreb, Croatia), previously heated to $90{ }^{\circ} \mathrm{C}$. The prepared drinks were left to cool to $40-45^{\circ} \mathrm{C}$ before they were served to the panellists in $100 \mathrm{~mL}$ plastic cups, starting from the sample $\mathrm{K}$ followed by the samples containing the liquid extract (from lower extract concentration to a higher one) and ending with the powders containing the microencapsulated extract, also from lower extract concentration to a higher one. Water was used for mouth rinsing.Attributes evaluated for the prepared drinks were: appearance, colour, odour, sweetness, aftertaste and hemp 
aroma. Sensory analysis was conducted at ambient conditions of $19^{\circ} \mathrm{C}$ and a relative humidity of $45 \%$.

\section{Data analysis}

The influence of the extract type and the concentration on the physical, chemical and sensory properties of cocoa powder enriched with the industrial hemp extract was carried out using the Wilcoxon equivalent pairs test, with a significance level $p<0.05$ in the Statistica v 8.0 statistical package (StatSoft, Tulsa, USA).

\section{RESULTS AND DISCUSSION}

Foam properties

Foam stability, density and dry matter content are shown in Table 1.

Table 1. Foam properties $(A=$ samples with microencapsulated hemp extract, $E=$ samples with liquid hemp extract).

\begin{tabular}{|c|c|c|c||}
\hline Sample & Stability [\%] & Density [g/mL] & Dry matter [\%] \\
\hline $\begin{array}{c}\text { Control } \\
(\mathrm{K})\end{array}$ & $100.00 \pm 0.00$ & $0.74 \pm 0.01$ & $46.81 \pm 1.27$ \\
\hline A2.5 & $93.30 \pm 0.45$ & $0.52 \pm 0.01$ & $46.68 \pm 0.20$ \\
\hline A5 & $97.82 \pm 2.17$ & $0.63 \pm 0.01$ & $45.96 \pm 1.13$ \\
\hline A10 & $95.72 \pm 0.27$ & $0.59 \pm 0.01$ & $43.55 \pm 0.43$ \\
\hline A15 & $97.62 \pm 2.38$ & $0.64 \pm 0.02$ & $43.67 \pm 0.62$ \\
\hline E2.5 & $94.86 \pm 1.56$ & $0.51 \pm 0.02$ & $46.77 \pm 0.26$ \\
\hline E5 & $94.05 \pm 2.38$ & $0.59 \pm 0.01$ & $43.80 \pm 2.40$ \\
\hline E10 & $95.74 \pm 0.09$ & $0.61 \pm 0.02$ & $42.07 \pm 0.50$ \\
\hline E15 & $92.29 \pm 0.29$ & $0.55 \pm 0.01$ & $39.98 \pm 1.35$ \\
\hline
\end{tabular}

Results are shown as mean $(n=3) \pm S D$.

Foam stability is the ability of the foam and its continuous phase to keep the gas phase in its structure for a certain period of time. If the foam has the ability to keep gas phase in its structure for a longer period of time, its stability will be greater and vice versa (Narsimhan and Xiang, 2018). In this research, the greatest foam stability (Table 1) was detected for the control sample without hemp extract addition, while the stability of the samples with extracts was slightly lower. When comparing the extract type, it was visible that the samples with the microencapsulated extracts (A) had higher foam stability in comparison to the ones with the liquid extract (E), which was confirmed by the Wilcoxon matched pairs test $(p=0.0077)$. No evident rise/fall trend was detected for the influence of the extract concentration on the foam stability either. Foam stability values for all samples were above $90 \%$, indicating that the egg white was a suitable foaming agent. Density values ranged from 0.51 (sample E2.5) to $0.74 \mathrm{~g} / \mathrm{mL}$ (sample K). In this case higher foam density was determined for the control sample while extract addition lowered the foam density values and trapping more air inside the foam, which has a favorable effect on heat and mass transfer during the drying process. Liquid extract addition lowered the density values to a greater extent in comparison to the microencapsulated extract, which was also confirmed by the
Wilcoxon test $(p=0.0077)$. Dry matter content of the foam ranged from 39.98 (E15) to $46.81(\mathrm{~K})$ and was defendant on both, the extract type and the extract concentration. Samples with lower extract content had higher dry matter content and the microencapsulated extract containing samples had higher dry matter content in comparison to those with the liquid extract.

After drying and milling, a powdered cocoa product was obtained. Physical properties of the cocoa powders enriched with hemp extract are shown in Table 2.

Dry matter values ranged from 97.16 (E10) to $97.94 \%$ (E2.5). The highest dry matter values were obtained for samples A2.5 and E2.5 (both containing 2.5\% of hemp extract) and the lowest ones for samples A15 and E10. From the obtained results it can be concluded that by adding the extract at higher concentrations, a bigger dry matter content reductionwas obtained and such a reduction of the dry matter content was more pronounced for samples containing the liquid form of the extract $(p=0.0076)$. Considering the parameters $d(0,5)$ and $\mathrm{D}[3,2]$, the largest particle size was detected for the sample A15 $(\mathrm{d}(0.5)=184.730$ and $\mathrm{D}[3,2]=83.283 \mu \mathrm{m})$. It can be noticed that, the particle size increased with the percentage of the added extract, whereas the form in which the extract is added (microencapsulated or liquid) did not have a significant effect on the particle size.

Bulk density values shown in Table 2 were evaluated by a jolting volumeter after 10 taps and ranged from $640.47 \mathrm{~g} / \mathrm{mL}$ (sample K) to $713.95 \mathrm{~g} / \mathrm{mL}$ (sample A10). The extract containing samples had higher bulk density in comparison to the control sample and that the samples with liquid extract had higher bulk density in comparison to the microencapsulated ones, with an exception of sample A10. Percentage of the added extract did not affect the bulk density significantly $(p>0.05)$.

An evident effect of the extract type was visible for the cohesion index values, where the microencapsulated extract caused a significant increase in the cohesion index values, characterizing the samples as cohesive (A5), very cohesive (A10 and A15) or even extremely cohesive (A2.5). On the other hand, samples with liquid extracts had significantly lower cohesion index values, which put them in the category of free flowing powders, according to a classification previously reported by Benković et al. (2013).

As stated by Fang et al. (2007), in order to have good reconstitution properties, a powder must be readily dissolvable and dispersible in a solvent. Dispersibility and solubility of the hemp enriched cocoa powders is shown in Figure 1.

Table 2. Cocoa powder properties $(A=$ samples with microencapsulated hemp extract, $E$ = samples with liquid hemp extract).

\begin{tabular}{|c|c|c|c|c|c||}
\hline Sample & $\begin{array}{c}\text { Dry matter } \\
{[\%]}\end{array}$ & $\begin{array}{c}\mathrm{d}(0.5) \\
{[\mu \mathrm{m}]}\end{array}$ & $\begin{array}{c}\mathrm{D}[3,2] \\
{[\mu \mathrm{m}]}\end{array}$ & $\begin{array}{c}\text { Bulk density } \\
\text { after 10 taps } \\
{[\mathrm{g} / \mathrm{mL}]}\end{array}$ & $\begin{array}{c}\text { Cohesionindex } \\
{[\mathrm{mm}]}\end{array}$ \\
\hline $\begin{array}{c}\text { Control } \\
(\mathrm{K})\end{array}$ & $97.55 \pm 0.02$ & $186.66 \pm 4.41$ & $66.32 \pm 2.33$ & $640.47 \pm 7.55$ & $11.89 \pm 0.08$ \\
\hline A2.5 & $97.74 \pm 0.03$ & $134.24 \pm 0.44$ & $54.01 \pm 0.09$ & $646.80 \pm 5.23$ & $21.08 \pm 0.72$ \\
\hline A5 & $97.63 \pm 0.03$ & $174.08 \pm 3.15$ & $74.05 \pm 1.04$ & $655.53 \pm 5.23$ & $15.45 \pm 0.08$ \\
\hline A10 & $97.41 \pm 0.04$ & $173.19 \pm 0.53$ & $70.14 \pm 0.08$ & $713.95 \pm 11.45$ & $16.16 \pm 0.36$ \\
\hline A15 & $97.23 \pm 0.02$ & $184.73 \pm 3.67$ & $83.28 \pm 1.72$ & $642.59 \pm 6.32$ & $16.13 \pm 0.36$ \\
\hline E2.5 & $97.94 \pm 0.01$ & $132.14 \pm 1.41$ & $49.93 \pm 1.27$ & $663.27 \pm 6.66$ & $16.69 \pm 1.52$ \\
\hline E5 & $97.41 \pm 0.05$ & $165.54 \pm 0.56$ & $67.28 \pm 0.16$ & $698.41 \pm 7.11$ & $10.46 \pm 0.39$ \\
\hline E10 & $97.16 \pm 0.02$ & $180.02 \pm 1.84$ & $71.35 \pm 0.70$ & $653.41 \pm 12.40$ & $12.15 \pm 0.48$ \\
\hline E15 & $97.34 \pm 0.01$ & $141.15 \pm 1.27$ & $53.42 \pm 0.14$ & $682.94 \pm 11.36$ & $12.91 \pm 0.18$ \\
\hline
\end{tabular}

Results are shown as mean $(n=3) \pm S D$. 



Fig. 1. Reconstitution properties of hemp extract enriched cocoa powder: a) solubility, b) dispersibility

In Fig. 1a., solubility is shown as a volume of the undissolved sediment left in the Falcon cuvette after centrifugation. The highest amount of sediment, and thus the lowest solubility was determined for the sample E5, followed by the samples K, E2.5, and E10 containing the liquid extract. It was also evident that the addition of the liquid extract lowered the solubility of the powders, as confirmed by the Wilcoxon test ( $p=0.0077$ ). Furthermore, the addition of the extract in any given form enhanced the solubility of the powder, and better solubility values were obtained for samples containing higher concentrations of the extracts $(p=0.0208)$. Similar to the solubility, the dispersibility was also affected by the concentration of the extract: more extract also meant longer time required to disperse the powder in water (Fig. 1b). Samples with the addition of the liquid extract $(\mathrm{E})$ showed a slightly higher increase in dispersibility times compared to the microencapsulated ones (A).

\section{Chemical properties}

Chemical properties of the hemp enriched cocoa powders were evaluated as the content of the total polyphenols and the antioxidant capacity measured by the DPPH method. The results are shown in Figure 2.

The highest proportion of polyphenols in prepared cocoa mixtures was seen for samples A2.5 and E2.5, followed by A5 and E5 (Fig. 2). The control sample (K) contained 2.26 mgGAE/g extract of total polyphenols, which was similar as samples A10 and E10 (2.68 and $2.21 \mathrm{mgGAE} / \mathrm{g}$ extract, respectively) while the lowest total polyphenol content was detected for samples A15 and E15. From the obtained results it can be concluded that, the addition of the hemp extract is only beneficial to a certain extent, or, in this case, up to $5 \%$. Similar results were obtained byPižeta (2018), who concluded that, after optimization of the mint extract addition to cocoa powder, the optimum is achieved at $3.75 \%$, after which the dissolution effect kicks in due to high water content of the extract. Because of that, the use of lyophilized extract is suggested in future research. Similar effects were evident for the antioxidant capacity (Fig. 2), where only the E2.5 and A2.5 samples exhibited higher antioxidant capacity than the control sample.

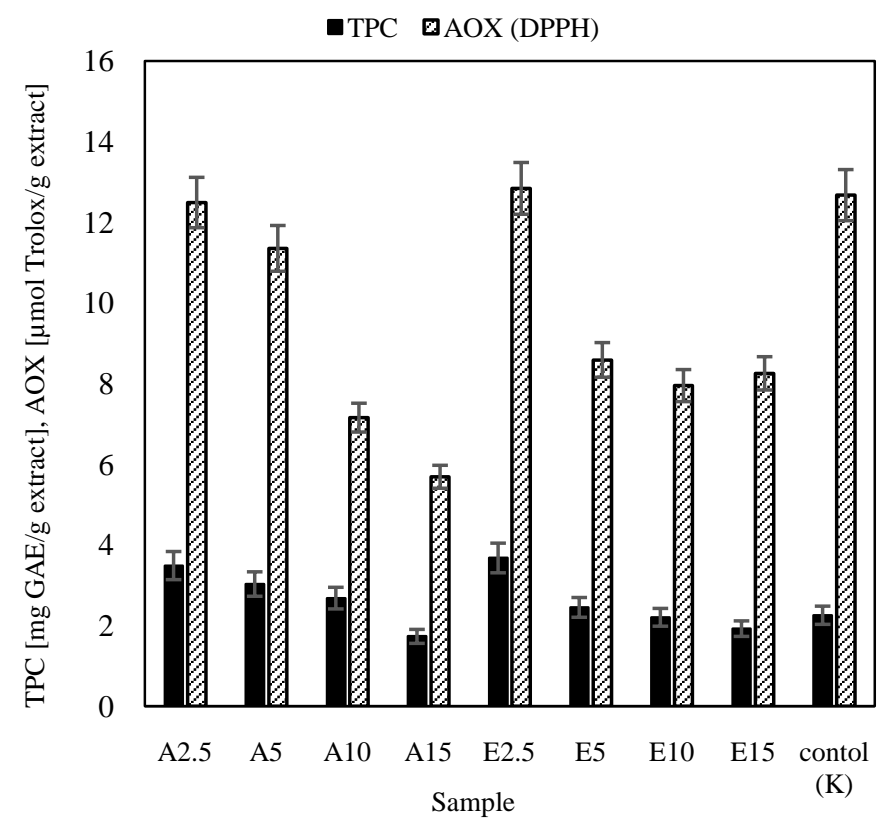

Fig. 2. Total polyphenolic content (TPC) and antioxidant capacity (AOX) determined by the DPPH method of the hemp enriched cocoa powders

\section{Sensory properties}

When developing a new functional product, besides functional properties, care has to be taken of the sensory acceptability of the product. Sensory scores for the prepared cocoa drinks are shown in Fig. 3.

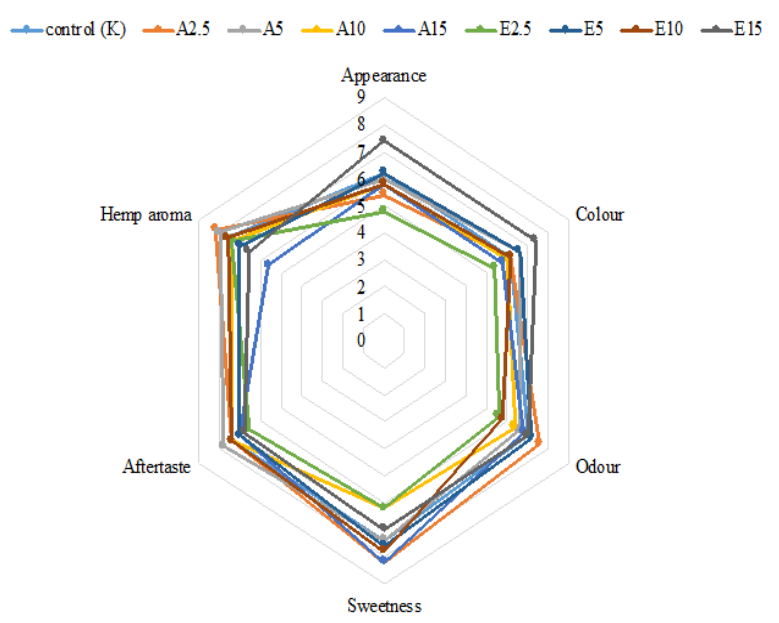

Fig. 3. Sensory evaluation of the hemp enriched cocoa drinks

Sensory analysis of the obtained cocoa samples was carried out using a panel group (five evaluators) evaluating six different sensory properties: appearance, colour, odour, sweetness, aftertaste and hemp aroma. These properties were evaluated on the hedonic scale where each parameter was rated from 1 to9 (1 indicates the least liking, while 9 indicates the highest liking). Based on the obtained results, the best sensory graded samples were A2.5, A5 and E15, while the worst graded ones was E2.5, with $2.5 \%$ of the liquid extract. Based on appearance, the best- 
rated sample was E15 with an average rating of 7.4, while the worst rated sample was E2.5 with an average grade of 4.8. For the colour property, the best graded sample was E15, with a grade of 7.4, and the worst E2.5 with a score of 5.4. For the odour properties, the A2.5 sample was rated best (7.6), while the E2.5 sample was rated only 5.6.

The highest graded samples based on sweetness were A2.5 and A15 with a score of 8.2, while the worst gradedwith a score of 6.2 were samples A10 and E2.5. For the aftertaste, the highest score of 7.8 was achieved by the A5 sample and the lowest the E2.5 sample. The highest average grade for the hemp aroma was 8.2 (A2.5), while the lowest grade was 5.6 (E2.5). It can be noticed that addition of different concentrations of extract did not result in better or worse sensory properties since the average rating of all sensory properties for all samples ranged between 6 and 7. However, noticeable differences were present when comparing the form in which the extract was added. Samples with the microencapsulated extract were better graded for hemp aroma, aftertaste and sweetness, while the samples with the added liquid extract were better graded for appearance and colour.

\section{CONCLUSIONS}

Influence of the hemp extract type and concentration on physical, chemical and sensory properties of cocoa powders produced by foam mat drying was explored in this research. Based on the obtained results it was visible that the type of the added extract affected powder dry matter, total polyphenolic content, antioxidant capacity, cohesion index and foam dry matter. The percentage of the added extract affected bulk density, all sensory properties and the total polyphenolic content. Percentage of the added extract had a more significant influence $(p<0.05)$ on the produced samples and their properties compared to the type of the added extract. When comparing flow properties, it was evident that the addition of the microcapsules caused an increase of the cohesion index. Furthermore, the addition of the hemp extract in concentrations of 2.5 and $5 \%$ w/w improved chemical (higher total polyphenolic content and antioxidant capacity) and sensory properties, while higher levels of added extract did not prove to be beneficial due to an intensive aftertaste and herbal aroma which affected sensory scores. The results of this study confirm the suitability of hemp extract as an ingredient in functional cocoa production, as well as the suitability of instant cocoa powders as matrices for functional supplements.

\section{REFERENCES}

Ackar, Đ., Valek Lendić, K., Valek, M., Šubarić, D., Miličević, B., Babić, J., Nedić, I. (2013). Cocoa polyphenols: can we consider cocoa and chocolate as potential functional food? Journal of Chemistry. 2013, article ID 289392, http://dx.doi.org/10.1155/2013/289392.

AOAC International (1990). Official Methods of Analysis $\left(15 \mathrm{t}^{\mathrm{h}}\right.$ ed.). Association of Official Analytical Chemists, Arlington, USA.

Baba, S., Natsume, M., Yasuda Arlington, A. (2007). Plasma LDL and HDL cholesterol and oxidized LDL concentrations are altered in normo- and hyper cholesterolemic humans after intake of different levels of cocoa powder. Journal of Nutrition, 137(6), 1436-1441.

Badrie, N., Bekele, F., Sikora, E., Sikora, M. (2015). Cocoa agronomy, quality, nutritional, and health aspects. Critical Reviews in Food Science and Nutrition, 55(5), 620-659.

Benković, M., Bauman, I. (2012). Agglomeration of cocoa powder mixtures - influence of process conditions on physical properties of the agglomerates. Journal of Energy and Processing in Agriculture 15(1), 46-49.

Benković, M., Bauman, I. (2009). Flow properties of powdered infant formula. Journal of Energy and Processing in Agriculture 13(1), 76-70.

Benković, M., Srečec, S., Špoljarić, I., Mršić, G., Bauman, I. (2013). Flow properties of commonly used food powders and their mixtures. Food and Bioprocess Technology, 6(9), 25252537.

Brand-Williams, W., Cuvelier, M.E., Berset, C. (1995). Use of a free radical method to evaluate antioxidant activity, LWT Food Science and Technology, 28, 25 - 30.

Cinquanta, L., Di Cesare, C., Manoni, R., Piano, A., Roberti, P., Salvatori, G. (2016). Mineral essential elements for nutrition in different chocolate products. International Journal of Food Science and Nutrition, 67(7), 773-778.

Fang, Y., Selomulya, C., Chen, X.D. (2007). On Measurement of food powder reconstitution properties. Drying Technology, 26(1), 3-14.

Haugaard-Sørensen, I., Krag, J., Pisecky, J., Westergaard, V. (1978). Analytical methods for dry milk products. Niro Atomizer. Copenhagen, Denmark.

Hazekamp, A., Grotenhermen, F. (2010). Review on clinical studies with cannabis and cannabinoids 2005-2009. Cannabinoids, 5, 1-21.

Hollenberg, N.K., Fisher, N.D.L., McCullough, M.L. (2009). Flavanols, the Kuna, cocoa consumption, and nitricoxide. Journal of the American Society of Hypertension, 3(2), 105112.

Lachman, J., Hosnedl, V., Pivec, V., Orsák, M. (1998). Polyphenols in cereals and their positive and negative role in human and animal nutrition. Proceedings of Conference Cereals for Human Health and Preventive Nutrition. Agricultural Research Institute Kroměříž, Brno, Czech Republic, 118-125.

Narsimhan, G., Xiang, N. (2018). Role of proteins on formation, drainage, and stability of liquid food foams. Annuual Reviews in Food Science, 9, 1-21.

Ndife, J., Bolaji, P., Atoyebi, D., Umezuruike, C. (2013). Production and quality evaluation of cocoa products (plain cocoa powder and chocolate). American Journal of Food and Nutrition, 3(1), 31-38.

Pižeta, M. (2018) Optimiranje procesa proizvodnje praškastih kakao napitaka obogaćenih ekstraktom mente. Diplomski rad. Prehrambeno-biotehnološki fakultet, Zagreb, Croatia.

Spence, J.T. (2006). Challenges Related to the composition of funtional foods. Journal of Food Composition and Analysis, 19, 4-6.

Živković, J., Košutić, M., Cvetković, B., Vukelić, N., Filipčev, B. (2013). Consumers perception in functional food in Serbia. Journal of Energy and Processing in Agriculture 17(3), 138 140.

Received: 19. 02. 2019.

Accepted: 18. 03. 2019. 